\title{
ENHANCING CUSTOMER SATISFACTION IN TERMS OF SERVICE QUALITY IN SUPERMARKET - THE CASE STUDY OF BIG C SUPERMAKET IN HCMC
}

\author{
Trinh Thuy Anh, Ho Chi Minh City Open University \\ Phan Minh Tai, Saigon M\&C Real Estate JSC
}

\begin{abstract}
This paper aimed at determining factors effecting customer satisfaction in terms of service quality as well as evaluating satisfaction level of shoppers in Big C Supermarket. A survey of 158 shoppers in various Big C supermarkets in HCMC has evaluated retail service quality according to Retail Service Quality Scale (RSQS) which composes of 5 dimensions namely physical aspects, reliability, personal interaction, problem solving and policy. The findings show that there are three factors mainly effecting on customer satisfaction in Big C, those factors are Reliability, Problem Resolving and Policy. Based on the result of survey, practicle solutions recommended to Big $C$ for improvement of service quality in order to close gaps that could lead to increasing customer satisfaction.
\end{abstract}

Keywords: customer satisfaction, service quality, RSQS, supermarket, HCMC.

\section{INTRODUCTION}

According to statistics, up to 2011, there were 450 supermarkets, around 80 commercial centers and over 2,000 stores all over Vietnam. Besides the modern distribution system, there were 8,591 traditional markets and about 1,200 temporaty markets. The existing of many retail distribution channels bring customers many choices of shopping. Therefore, the competition between traditional markets, Supermarkets, etc. become more fierce. To survive and develop in the current economic situation, a business has to understand the customers' perceptions toward its service quality then has the proper improvements to meet customers' expectation, that will create an advantage of getting customers' intimacy. Basing on that rationale, this paper concerns on assessing current service quality of a modern supermarket (a common retail model in big cities in Vietnam) and finding solutions to enhance it.
Among players in Vietnam retail market, HCMC Big C Supermaket was chosen (a modern retail business is managed under the umbrella of Casino group) which many Vietnam people are familiar with.

\section{LITERATURE REVIEW}

Customer satisfaction

Shortly, customer satisfaction is defined as "overall attitude towards a service provider" (McDougall, 1990) or "an emotional reaction to the difference between what customers anticipate and what they receive" (Zineldin, 2000).

Zeithaml V.A. (2006) interprets that customer satisfaction is influenced by perceptions of five factors: service quality, product quality, price, situational factors such as family member opinions, and personal factors such as customer's mood or emotional state.

Service quality is one of the elements 
that affect strongly to satisfaction of customer. It also indicates that the higher service quality customers perceive, the more satisfied they are. In five elements affecting customer satisfaction, Service qualiy is choosen for this paper in order to enhance satisfaction level of Big C's customers.

Service Quality and Measuring Scales for Retail Industry

In the past decades, many practitioners and researchers has paid attention to service quality for retail. Amongst various service quality models proposed, three models are used widely: SERVQUAL and GAP model, SERVPERF, and Retail Service Quality Model (RSQS).

Servqual Scale (by Parasuraman et al.) includes five dimensions tangibles, reliability, responsiveness, assurance and empathy. According to this model, there are five gaps which influence customer's perception toward sevice quality. These gaps occur in the internal process of delivering service, they define the difference between what is expected and what is perceived clarified the basic premise (Parasuraman et al, 1985).

Based on findings from Parasurman et al, Cronin and Taylor (1992) developed a service quality measurement as "performance - based" called SERVPERF. Theoriticallytheprevious researchexplored the decisive factors affecting the customer perception on service. Cronin and Taylor made a further step into operationalizing service quality measurement. Different from SERVQUAL in a combination of expectations and perceptions, SERVPERF maintains only what exists in the mind of customer (customer's perceptions for service quality).

Dabholkar et al. (1996) developed a spatial model of 28-item scale called Retail Service Quality Model (RSQS) to apply into retail industry, 28 items of scale includes 17 items kept from SERVPERF scale and 11 items found out from a qualitative research and are devided into 5 dimentions which are Physical aspects, Reliability, Personal interaction, Problem solving, Policy.

Physical aspects: Physical aspects are widely recognized as the factor of evaluation process of service quality. Three forces primarily cause the assessment: equipment and fixtures, physical facilities, materials. Accordingly, the authors define ease of physical ammenities and layouts. Their perspectives are concerned with tangible dimension and more meaningful than SERVQUAL is. The layout of physical facilities also has been put in high consideration. The more favorable comments on physical we receive, the better our service is.

Reliability: The researcher not there is no difference between reliability construction in their models in a comparision with SERVQUAL model. Reliability can be described as keeping promise, offering exact service, remaining the availability of merchandise and recording error-free sales transactions. They notice that marketing needs to address reliability as their own positive features in obtain customer service satisfactions.

Personal Interaction: The dimension of personal interaction is another variable that affect service quality assessment. It is made based on staffs knowledge to answer questions, stimulating confidence, giving service offers, keen to take action to customer's requests, paying attention to giving private customers, staying consistent courtesy with customers and even treating all your phone customers properly. The more favorable interpersonal contact, the greater the likelihood of good service evaluation is. 
Problem Solving: Problem solving examines the solution of returns, exchanges and complaints. The researchers categorize problem handling into two continums: willingness to solve return and exchange matters and sincere interest in dealing with customer complaints promptly.

Policy: In scope of retail industry, policy from retailers put a straight affect on service quality. It comes from upscale quality merchandise, easy access of parking and working hours as well as main credit card acceptance. The fact that policy could be highly appreciated is consistent with favorable evaluation within service management.

Servqual and Servperf are measuring scales applied into many types of service industries (retailing, banking, restaurants,...), however, each specific service industry has its own characteristic. These general scales therefore should be tested and revised carefully to fit particular traits of that service. Retail Service Quality Scale (RSQS) was developed from results of Servqual and Servperf to build a new scale which used to measure quality of retail service only. In many earlier studies, this model was used as an appropriate instrument to measure service quality in certain types of retailers such as department stores, supermarkets and discount stores over the the world, in Western and Eastern countries as well as in Vietnam.

After Dabholkar, Thorpe and Rentz (1996) replicated their own study and found all RSQS dimensions and subdimensions to be valid in the US, Mehta, Lalwani and Han (2000) found the RSQS five - dimensional structure appropriate for measuring the service quality perceptions of supermarket consumers in Singapore. According to Kim and Jin (2002), RSQS is a useful scale for measuring service quality of discount stores across two different cultural contexts of the US and South Korea though they reported empirical support for a four-and not a five-dimensional structure. Boshoff and Terblanche (1997), in a replication of the Dabholkar, Thorpe and Rentz (1996) study, report highly encouraging results for the RSQS applicability in the context of department stores, specialty stores, and hypermarkets in South Africa.

Nguyen Thi Mai Trang (Journal of Science and Technology Development - Social Sciences Humanitites and Management, Vol. 9 No 10, pp.57-70, 2006) describe service quality formation. She encountered the issue in term of the associations between service quality, customer satisfaction and loyalty in supermarkets in HCMC. Nguyen Dang Duy Nhat \& Le Nguyen Hau (Journal of Science and Technology Development - Social Sciences Humanitites and Management, Vol. 10, No 08, 2007) also made a research of identifying components of retail service quality in Vietnamese Supermakets. Basing on argument above, RSQS is the most suitable for this paper.

\section{RESEARCH METHODOLOGY}

\section{Research Method}

The objective of this study is to investigate satisfaction of customers in terms of service quality. The result of the paper can help Big C supermaket improve the service quality, retain current customers, attract new customers and get more profit. Retail Service Quality Scale (RSQS) shall be used for this research.

Research model consists of five factors basing on RSQS with hypothesis as following:

H1: Physical aspects have positive impact on overall evaluation of retail service quality.

H2: Reliability has positive impact on overall evaluation of retail service quality. 
H3: Personal interaction has positive impact on overall evaluation of retail service quality.

H4: Problem solving has positive impact on overall evaluation of retail service quality.

H5: Policy has positive impact on overall evaluation of retail service quality.

To determine which factors impacting on customer satisfaction, linear regression analysis is applied. Linear regression model is a regression form in which the relationship between dependent variables (dimensions of service quality) and independent variable (customer satisfaction) is described by a linear function in order to explain the impact of changes in a independent variable on the dependent variable (Berenson et al. 2004). Linear regression equation is represented as below

$$
\mathrm{Y}=\hat{\mathrm{a}}_{0}+\hat{\mathrm{a}}_{1} \mathrm{x}_{\mathrm{i}}+\stackrel{\mathrm{a}}{\mathrm{i}}_{\mathrm{i}}
$$

Where Y: dependent variable (dimension of customer satisfaction)

$\mathrm{X}_{\mathrm{i}}$ : dependent variable (dimensions of service quality)

$\beta_{0}:$ intercept

$\beta_{1}$ : slope coefficient

$\varepsilon_{\mathrm{i}}:$ random error (residual)

After determing specific factors impacting on customer satisfaction, theory of Gap 5 in Five Gaps Model will be applied to evaluate customer satisfaction level for those factors. According to Parasuraman and associates (1988), gap scores is the best most effective way to assess customer satisfaction, Gap scores are obtained by subtracting perception scores from expectation scores.

Gap score $=$ Perceptions $(\mathrm{P})-$ Expectations (E)

The highest score of satisfaction indicates customers' expectation.
Perceptions will base on mean value of scores for variables.

\section{Items building and survey}

The research is carried out through two main stages: pilot study which has been conducted by qualitative research via group discussion/ trial interview to construct and test measuring scales, actual study has been conducted by quantitative research to get primary data for analysis.

Customer satisfaction of shopping in Big C supermarket is theoretically affected by five dimensions that are Physical aspects (PHY), Reliability (REL), Personal interaction (PER), Problem solving (PRO), Policy (POL).

Original RSQS model of Dabholkar including 28 dependent variables. Dependent variable is dimension of customer satisfaction including three questions based on framework proposed by Lassar et al (2000) for customer satisfaction: (1) overall satisfaction level about service, (2) recommendation of current customer to potential customer, (3) continuing of using service.

After a qualitative survey, one variable (question number 28) of Policy dimension removed from scale due to unsuitable to supermarket in Vietnam, most of members in group discussion agreed this conclusion. Therefore, the official questionnaire includes 30 questions formally, 27 questions from RSQS and 3 questions from customer satisfaction theory.

Sample size depends on data analysis method. Factor analysis need sample size at least five times of observed variables (Hair, 1994). The number of observed variables in research model is 30 . So sample size need at least $30 \times 5=150$ responses 
Table 1: Service quality and Customer satisfaction scale

\begin{tabular}{|c|c|c|c|}
\hline No. & Label & Description & Source \\
\hline \multicolumn{4}{|c|}{ Physical aspects (PHY) } \\
\hline 01 & PHY_01 & Big $\mathrm{C}$ has modern-looking equipment and fixtures & $\begin{array}{l}\text { Servperf } \\
\text { Scale }\end{array}$ \\
\hline 02 & PHY 02 & $\begin{array}{l}\text { Big } \mathrm{C} \text { and its physical facilities (trial rooms and restrooms) are } \\
\text { visually attractive }\end{array}$ & $\begin{array}{l}\text { Servperf } \\
\text { Scale }\end{array}$ \\
\hline 03 & PHY 03 & $\begin{array}{l}\text { Materials associated with Big C's service (such as shopping bags, } \\
\text { loyalty cards, and catalogues) are visually appealing }\end{array}$ & $\begin{array}{l}\text { Servperf } \\
\text { Scale }\end{array}$ \\
\hline 04 & PHY _04 & $\begin{array}{l}\text { Big C has clean, attractive, and convenient physical facilities } \\
\text { (restrooms, fitting rooms) }\end{array}$ & $\begin{array}{l}\text { RSQS } \\
\text { Model }\end{array}$ \\
\hline 05 & PHY 05 & $\begin{array}{l}\text { The layout of Big C makes it easier for customers to find what they } \\
\text { need }\end{array}$ & $\begin{array}{l}\text { RSQS } \\
\text { Model }\end{array}$ \\
\hline 06 & PHY_06 & $\begin{array}{l}\text { The layout of Big C makes it easier for customers to move around } \\
\text { in store }\end{array}$ & $\begin{array}{l}\text { RSQS } \\
\text { Model }\end{array}$ \\
\hline \multicolumn{4}{|c|}{ Reliability (REL) } \\
\hline 07 & REL_01 & $\begin{array}{l}\text { When Big C promises to do something (such as repairs, alterations) } \\
\text { by a certain time, it will do so }\end{array}$ & $\begin{array}{l}\text { Servperf } \\
\text { Scale }\end{array}$ \\
\hline 08 & REL_02 & Big $\mathrm{C}$ provides its services at the time it promises to do so & $\begin{array}{l}\text { Servperf } \\
\text { Scale }\end{array}$ \\
\hline 09 & REL_03 & Big $\mathrm{C}$ performs the service right the first time & $\begin{array}{l}\text { Servperf } \\
\text { Scale }\end{array}$ \\
\hline 10 & REL_04 & Big $\mathrm{C}$ has merchandise available when the customers want it & $\begin{array}{l}\text { RSQS } \\
\text { Model }\end{array}$ \\
\hline 11 & REL_05 & Big C insists on error-free sales transactions and records & $\begin{array}{l}\text { Servperf } \\
\text { Scale }\end{array}$ \\
\hline \multicolumn{4}{|c|}{ Personal Interaction (PER) } \\
\hline 12 & PER_01 & $\begin{array}{l}\text { Employees in Big } \mathrm{C} \text { have the knowledge to answer customers' } \\
\text { questions }\end{array}$ & $\begin{array}{l}\text { Servperf } \\
\text { Scale }\end{array}$ \\
\hline 13 & PER_02 & The behaviour of employees in Big C instils confidence in customers & $\begin{array}{l}\text { Servperf } \\
\text { Scale }\end{array}$ \\
\hline 14 & PER_03 & Customers feel safe in their transactions with Big C & $\begin{array}{l}\text { Servperf } \\
\text { Scale }\end{array}$ \\
\hline 15 & PER_04 & The employees in Big C give prompt service to customers & $\begin{array}{l}\text { Servperf } \\
\text { Scale }\end{array}$ \\
\hline 16 & PER_05 & $\begin{array}{l}\text { Employees in Big C tell customers exactly when services will be } \\
\text { performed }\end{array}$ & $\begin{array}{l}\text { Servperf } \\
\text { Scale }\end{array}$ \\
\hline 17 & PER_06 & $\begin{array}{l}\text { Employees in Big C are never too busy to respond to customer's } \\
\text { requests }\end{array}$ & $\begin{array}{l}\text { Servperf } \\
\text { Scale }\end{array}$ \\
\hline 18 & PER_07 & Big $\mathrm{C}$ gives customers individual attention & $\begin{array}{l}\text { Servperf } \\
\text { Scale }\end{array}$ \\
\hline 19 & PER_08 & Employees in Big C are consistently courteous with customers & $\begin{array}{l}\text { Servperf } \\
\text { Scale }\end{array}$ \\
\hline
\end{tabular}




\begin{tabular}{|c|c|c|c|}
\hline 20 & PER_09 & Employees in Big C treat customers courteously on the telephone. & $\begin{array}{l}\text { RSQS } \\
\text { Model }\end{array}$ \\
\hline \multicolumn{4}{|c|}{ Problem Solving (PRO) } \\
\hline 21 & PRO_01 & Big $\mathrm{C}$ willingly handles returns and exchanges & $\begin{array}{l}\text { RSQS } \\
\text { Model }\end{array}$ \\
\hline 22 & PRO_02 & $\begin{array}{l}\text { When a customer has a problem, Big C shows a sincere interest in } \\
\text { solving it }\end{array}$ & $\begin{array}{l}\text { Servperf } \\
\text { Scale }\end{array}$ \\
\hline 23 & PRO_03 & $\begin{array}{l}\text { Employees of Big C are able to handle customer complaints directly } \\
\text { and immediately. }\end{array}$ & $\begin{array}{l}\text { RSQS } \\
\text { Model }\end{array}$ \\
\hline \multicolumn{4}{|c|}{ Policy (POL) } \\
\hline 24 & POL_01 & Big $\mathrm{C}$ offers high quality merchandise & $\begin{array}{l}\text { RSQS } \\
\text { Model }\end{array}$ \\
\hline 25 & POL_02 & Big C provides plenty of convenient parking for customers & $\begin{array}{l}\text { RSQS } \\
\text { Model }\end{array}$ \\
\hline 26 & POL_03 & Big $\mathrm{C}$ has operating hours convenient for all their customers & $\begin{array}{l}\text { Servperf } \\
\text { Scale }\end{array}$ \\
\hline 27 & POL_04 & Big $\mathrm{C}$ accepts all major credit cards & $\begin{array}{l}\text { RSQS } \\
\text { Model }\end{array}$ \\
\hline \multicolumn{4}{|c|}{ Customer satisfaction (SAS) } \\
\hline 28 & SAT_01 & You are satisfied when shopping in Big C Supermarket. & \multirow{3}{*}{ Custmer } \\
\hline 29 & SAT_02 & $\begin{array}{l}\text { You will increase the frequency of shopping in supermarket in the } \\
\text { future. }\end{array}$ & \\
\hline 30 & SAT_03 & You will continue to shop in Big C Supermarket in the future & \\
\hline
\end{tabular}

To get the rate of answers, Likert five points scale is used for measuring satsfaction level of customer basing on rule: 1 for very disagreed (the less satisfied), 2 for disagreed, 3 for neutral, 4 for agreed and 5 for strongly agreed (the most satisfied).

\section{RESULT ANALYSIS AND FINDINGS}

\subsection{Result analysis}

Using SPSS version 16.00 to analyse the result. Firsly, checking reliability of Scales by Cronbach's alpha index in order to ensure the measuring scale is reliable and consistent. The result shows that all Cronbach's alpha of dimensions are higher 0.7 and no Corrected Item-Total Correlation of any variable less than 0.33 , the scale therefore is reliability and kept unchanged (no variable rejected). Table 2 shows the result in detail. 
Table 2 : Cronbach's Alpha Coefficient

\begin{tabular}{|c|c|c|c|c|}
\hline Variables & $\begin{array}{l}\text { Scale Mean if } \\
\text { Item Deleted }\end{array}$ & $\begin{array}{l}\text { Scale Variance if } \\
\text { Item Deleted }\end{array}$ & $\begin{array}{l}\text { Corrected Item-Total } \\
\text { Correlation }\end{array}$ & $\begin{array}{c}\text { Cronbach's Alpha if Item } \\
\text { Deleted }\end{array}$ \\
\hline \multicolumn{5}{|c|}{ PHYSICAL (PHY): Alpha $=0.889$} \\
\hline PHY_01 & 17.54 & 11.231 & .805 & .855 \\
\hline PHY_02 & 17.56 & 11.879 & .694 & .872 \\
\hline PHY_03 & 17.86 & 12.184 & .637 & .881 \\
\hline PHY_04 & 17.53 & 11.270 & .828 & .852 \\
\hline PHY_05 & 17.30 & 11.767 & .615 & .885 \\
\hline PHY_06 & 17.33 & 10.732 & .696 & .875 \\
\hline \multicolumn{5}{|c|}{ RELIABILITY (REL): Alpha $=0.846$} \\
\hline REL_01 & 13.95 & 6.087 & .686 & .805 \\
\hline REL_02 & 13.89 & 6.688 & .709 & .805 \\
\hline REL_03 & 13.90 & 6.194 & .746 & .790 \\
\hline REL_04 & 13.85 & 6.754 & .468 & .867 \\
\hline REL_05 & 14.04 & 6.075 & \begin{tabular}{l|l}
.702 \\
\end{tabular} & .801 \\
\hline \multicolumn{5}{|c|}{ PERSONAL INTERACTION (PER): Alpha = 0.924} \\
\hline PER_01 & 26.64 & 23.557 & \begin{tabular}{l|l}
.724 &
\end{tabular} & .916 \\
\hline PER_02 & 26.60 & 22.407 & .807 & .910 \\
\hline PER_03 & 26.60 & 22.063 & .829 & .909 \\
\hline PER_04 & 26.72 & 22.256 & .833 & .909 \\
\hline PER_05 & 26.88 & 23.126 & .803 & .911 \\
\hline PER_06 & 26.93 & 23.976 & .693 & .918 \\
\hline PER_07 & 26.94 & 24.467 & .494 & .931 \\
\hline PER_08 & 26.74 & 22.856 & .712 & .917 \\
\hline PER_09 & 26.61 & 23.780 & \begin{tabular}{l|l}
.676 & \\
\end{tabular} & .919 \\
\hline \multicolumn{5}{|c|}{ PROBLEM SOLVING (PRO): Alpha = 0.898} \\
\hline PRO_01 & 6.62 & 2.084 & .766 & .881 \\
\hline PRO_02 & 6.64 & 2.041 & .801 & .852 \\
\hline PRO_03 & 6.72 & 1.963 & .827 & .828 \\
\hline \multicolumn{5}{|c|}{ POLICY (POL): Alpha = 0.738} \\
\hline POL_01 & 10.65 & 3.453 & .585 & .650 \\
\hline POL_02 & 10.94 & 3.252 & .421 & .766 \\
\hline POL_03 & 10.57 & 3.597 & .613 & .643 \\
\hline POL_04 & 10.58 & 3.493 & \begin{tabular}{l|l}
.560 \\
\end{tabular} & .664 \\
\hline \multicolumn{5}{|c|}{ CUSTOMER SATISFACTION (SAT): Alpha $=.855$} \\
\hline SAT_01 & 7.04 & 1.966 & .756 & .769 \\
\hline SAT_02 & 7.23 & 2.079 & .678 & .842 \\
\hline SAT_03 & 6.90 & 1.951 & .747 & .777 \\
\hline
\end{tabular}


After evaluating the reliability of measuring scale, factor analysis is apply to test if variable group of each dimension keeps unchanged or separates into different factors, and to reach to the underlying factors that have their most effect in customer satisfaction. As SPSS result, all KMO index much higher than 0.50 (the lowest one is 0.62 ) with significant level of Bartlett's Test of Sphericity - Sig. = 0.000. This indicates that using EFA is appropriate. All factor loadings of variables of six dimensions are higher than 0.5 , thus variables of each dimension are adequate to represent the data for each factor.

Correlation coefficient analysis was used for testing the relation between dimensions of service quality and customer satisfaction dimension. The result shows that the correlation between Customer Satisfaction (SAT) and Physical respect (PHY), Reliability (REL), Personal (PER) interaction, Problem resolving (PRO) and Policy (POL) are positive and statistically significant (Correlation coefficients between SAT and others are all higher than 0.33 with significants at the 0.01 level less than 0.00).

Linear regression run shows the result as table 1 , the significant level of regression coefficients of one Constant and five explanatory variables (Physical respect, Reliability, Personal interaction, Problem solving, Policy) are 0.950, 0.388, $0.021,0.225,0.002$ and 0.000 respectively.

Table 1: Regression: Coefficients ${ }^{\mathrm{a}}$

\begin{tabular}{|c|c|c|c|c|c|c|c|c|c|}
\hline \multirow[b]{2}{*}{ Model } & \multicolumn{2}{|c|}{$\begin{array}{c}\text { Unstandardized } \\
\text { Coefficients }\end{array}$} & \multirow{2}{*}{$\begin{array}{c}\begin{array}{c}\text { Standardized } \\
\text { Coefficients }\end{array} \\
\text { Beta }\end{array}$} & \multirow[b]{2}{*}{$\mathrm{T}$} & \multirow[b]{2}{*}{ Sig. } & \multicolumn{2}{|c|}{$\begin{array}{c}95 \% \text { Confidence } \\
\text { Interval for B }\end{array}$} & \multicolumn{2}{|c|}{$\begin{array}{l}\text { Collinearity } \\
\text { Statistics }\end{array}$} \\
\hline & B & Std. Error & & & & $\begin{array}{l}\text { Lower } \\
\text { Bound }\end{array}$ & $\begin{array}{l}\text { Upper } \\
\text { Bound }\end{array}$ & Tolerance & VIF \\
\hline Constant & .015 & .237 & & .063 & .950 & -.453 & .482 & & \\
\hline PHY & .067 & .078 & .066 & .865 & .388 & -.086 & .220 & .436 & 2.292 \\
\hline REL & .215 & .092 & .196 & 2.33 & .021 & .033 & .397 & .360 & 2.775 \\
\hline PER & .125 & .102 & .109 & 1.22 & .225 & -.077 & .327 & .321 & 3.117 \\
\hline PRO & .238 & .077 & .242 & 3.08 & .002 & .085 & .390 & .415 & 2.408 \\
\hline POL & .370 & .074 & .325 & 5.01 & .000 & .224 & .517 & .607 & 1.647 \\
\hline
\end{tabular}

Result shows that only three dimensions (Reliability, Problem solving, Policy) have the small significant level and can be accepted, so they are remained in the research model to explain for Customer Satisfaction. The regression equation of research model is bellow:

$\mathrm{SAT}=0.196 * \mathrm{REL}+0.242 * \mathrm{PRO}+0.325^{*} \mathrm{POL}$

Among three coefficients, coefficients of Policy (0.325) are much higher than coefficient of Problem Resolving (0.242) and Reliability (0.196). As the result, Reliability dimension Problem Resolving dimension have weaker influence to Customer Satisfaction than Policy dimension.

Basing on regression analysis result, the theoretical research model has been adjusted to be adequate to Big $\mathrm{C}$ supermarket context as following: 


\section{Figure 1: Final Adjusted Research Model}

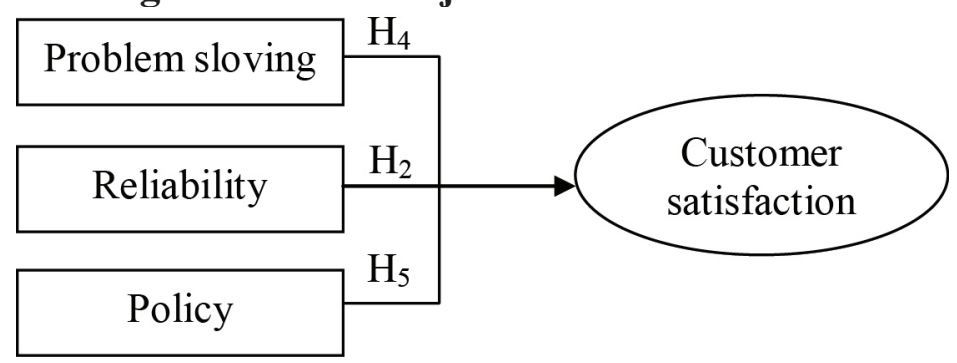

\subsection{Gap analysis}

Obtaining the score of each of three dimensions including 12 statements, the Gap score of the statements are calculated. According to Parasuraman and associate (1998) using gap scores is the most effective way to assess customer satisfaction. Gap score are obtained by subtracting perception scores from expectation scores.
Gap score = Perceptions (P) Expectation (E)

As mentioned aboved, the highest score of satisfaction (five on the five - point scale) indicated customers' expectation of shoping in Big $\mathrm{C}$ supermarket in general. Therefore all the expectation got the score of 5 .

Table 2: Gap Score

\begin{tabular}{|l|l|c|c|c|}
\hline \multirow{2}{*}{ No. } & \multirow{2}{*}{ Dimension } & \multicolumn{3}{|c|}{ Overall } \\
\cline { 3 - 5 } & & $\mathrm{P}$ & $\mathrm{E}$ & P-E \\
\hline 1 & Reliability & 3.48 & 5.00 & -1.52 \\
\hline 2 & Problem solving & 3.33 & 5.00 & -1.67 \\
\hline 3 & Policy & 3.56 & 5.00 & -1.44 \\
\hline 4 & Customer satisfaction & 3.53 & 5.00 & -1.47 \\
\hline
\end{tabular}

In comparision on gaps score between customer perception and expectation of retail service quality, the problem solving dimension got the most negative ratings and the Policy dimension received the least negative ratings.

\section{CONCLUSION RECOMMENDATION CONCLUSION}

From practical perspective, this research helps Big C Supermaket perceive the current level of service quality and customer satisfaction in the service they are providing, understand impact of different components affect the quality of service and customer satisfaction. From that, Big C Supermaket can have suitable modification to improve service quality and customer satisfaction.
This paper can be seen as a reference source contribute to customer satisfaction study of supermaket at a specific market.

\section{RECOMMENDATION}

The paper shows that customers although are quite satisfaction (but not very high) with current services and intend to continue shopping in Big $\mathrm{C}$ in future, but Big $\mathrm{C}$ has to improve a lot if it wants to continue developing and keep customers in this current difficult economy. Authors would like to give some final and overall recommendations to improve customer satisfaction as following.

Due to health issue, customers notice the quality and origin of goods most. Therefore, Big $\mathrm{C}$ should not only focus on the competitive price but also pay attention to the trustworthy quality. 
Recently, a number of Vietnam consumers avoid buying merchandises which have unclear origin or Chinese origin because of doubting quality, Big $\mathrm{C}$ should consider this market tendency.

HCMC is a biggest city in Vietnam and people have no habit of taking public transport, therefore, parking for vehicle is a big broblem of City. As a whole city, Big C supermarket is also facing this trouble and needs have the right solution to make customers more satisfied by ensuring enough space for them parking. A practical solution is multi-floor parking building which is pre-engineering steel structure. This construction can store a lot of vehicles, especially it is simple and takes short time to install.

Factors relating to the convenient operating hours and accepting all major credit card for payment are highly appreciated by customers, and Big C indeed has implemented these things well so it should uphold.

In doing business, Big $\mathrm{C}$ always has commitments with its customers regarding terms of return/ exchange/ repairs/ alternation for damaged/ error merchandises as well as giving feedback for complaints by customers. In fact, the research shows that these factors really make a strong impact on customer sastisafaction, however unfortunately the research also tells us that customers do not give Big $\mathrm{C}$ high score for these factors. Therefore, Big C promptly improves the customer service team to take care of customers better, as well as probably redefines the terms of return/ exchange/ repairs/ alternation for damaged/ error merchandises and giving feedback for complaints how to meet customers' expection (such as shortening the process time, making procedure simple and convenient).

In addition, Big $\mathrm{C}$ also should strengthen relationship with customers by building reliability on them through: always do right things at right time for any promises, ensure merchandises always available on the shelfs to avoid making customers disappointed when they come, make sure sales transactions smoothly and no mistakes, belongings of customer kept safety in locker when they are shopping.

\section{Limitation and future works}

Due to limited time, the survey only focuses on Service Quality, meanwhile Customer Satisfaction also affected by other components: product quality, price, situational factors and personal factors. In addition, the research is only conduct with customers who already shopped at Big C Supermarket in HCMC. The content of the research will be more comprehensive if subject of survey is going to open to other areas in Vietnam.

From limitation mentioned above, it is suggested for futher study in future could considerate product quality, price, situational factors as well as personal factors and then extending to other areas in Vietnam. This will have better and more confident result in investigating customer satisfaction due to larger sample size. Future study should be conduct in longer time for better result. The future study can apply modern statistical technique like structural equation modeling (SEM) for better result. 


\section{REFERENCE}

Gordon H.G. McDougall, Douglas W. Snetsinger, (1990) «The Intangibility of Services: Measurement and Competitive Perspectives», Journal of Services Marketing, Vol. 4 Iss: 4 , pp. $27-40$.

Mosad Zineldin, (2000) «Beyond relationship marketing: technologicalship marketing», Marketing Intelligence \& Planning, Vol. 18 Iss: 1, pp.9 - 23.

Zeithaml V.A., B. M. (2006). Services Marketing: Integrating customer focus accross the firm (4th ed.). McGraw-Hill/Irwin, p.107.

Kathryn Bishop Gagliano, Jan Hathcote, (1994) «Customer Expectations and Perceptions of Service Quality in Retail Apparel Specialty Stores», Journal of Services Marketing, Vol. 8 Iss: 1, pp.60-69.

Parasuraman A., Zeithaml V.A., and Berry L.L., A conceptual model of service quality and its implications for future research, (1985).

Parasuraman, A.; Leonard L.Zeithaml. Valarie A.; Berry, Leonard L. (1986-1998) "Perceived Service Quality as a Customer-Based Performance Measure: An Empirical examination of Organization Barriers using an Extended Service Quality Model" Human Resource Management.

Parasuraman, A.; Zeithaml. Valarie A.; Berry, Leonard L (1988). "Servqual: A Multipleitem scale of measuring consumer perception of service quality", Journal of Retailing.

Parasuraman. A; Berry L.; and Zeithaml V. (1991) "Refinement and Reassessment of the SERVQUAL Scale” Journal of Retailing 67, Winter 94).

Parasuraman. A; Leonard. L Berry; Valarie A Zeithaml (1996) "The behavioral consequences of service quality" Journal of Marketing: 60.

Cronin, J.J. \& Taylor, S.A (1992) "Measuring service quality: A reexamination and extension", Journal of Marketing, 56 (July):pp 55-68.

Lee, J., Lee,J. \& FEick, L. (2001) "The Impact of Switching Cost on the Customer Satisfaction Loyalty Link: Mobile phone Service in France", Journal of Service Marketing: pp. 35-48

Brady, M.K., Cronin, J.J. \& Brand, R.R., (2002) "Performance-only Measures of Service Quality: A Replication an Extension”, Journal of Business Research: pp. 17-31.

Dabholkar, P.; Thorpe, D. and Rentz, J. A Measure of Service Quality for Retail Stores: Scale Development and Validation, Journal of the Academy of Marketing Science, 24 (Winter),pp 3-16, (1996).

Nguyen, Thi Mai Trang, Service Quality, Customer Satisfaction and Loyalty: A study of supermarkets in Ho Chi Minh City, Journal of Science and Technology Development - Social Sciences Humanitites and Management, Vol. 9 No 10, pp.57-70, (2006)

Nguyen Dang Duy Nhat \& Le Nguyen Hau, Determinants of Retail Service Quality - a study of supermarkets in Vietnam, Journal of Science and Technology Development - Social Sciences Humanitites and Management, Vol. 10, No 08, pp.15-23 (2007)

Lassar, W.M., Manolis, C. \& Winsor, R.D. (2000) "Service quality perspectives and satisfaction in private banking”, International Journal of Bank Marketing.

Hair, J.F., Anderson, R.E., Tatham, R.L. and Black, W.C. Multivariate Data Analysis, 5 $^{\text {th }}$ 
edition. Prentice-Hall. New Jersey, (1998).

Farris, Paul W.; Neil T. Bendle; Phillip E. Pfeifer; David J. Reibstein (2010). Marketing Metrics: The Definitive Guide to Measuring Marketing Performance.

Hoang Ngoc Nham (2008). Econometric

Hoang Trong, Chu Nguyen Mong Ngoc (2005). Data analysis with SPSS 